\title{
PERANCANGAN SOUVENIR BERBAHAN KULIT BERCIRI KHAS UNIVERSITAS NEGERI YOGYAKARTA
}

\author{
Ismadi dan Iswahyudi \\ FBS Universitas Negeri Yogyakarta \\ E-mai: ismadi.andra7@gmail.com
}

\begin{abstract}
Abstrak
Penelitian ini merupakan penelitian dan pengembangan (Research and Development/R\&D) bertujuan untuk mengembangkan souvenir yang bercirikhas Universitas Negeri Yogyakarta. Penelitian ini menerapkan model penelitian dan pengembangan (Research and Development $R \& D$ ) yang dikembangkan Sugiyono (2013: 409) dengan garis besar: 1) potensi dan masalah; 2) pengumpulan data; 3 ) desain produk; 4) evaluasi desain produk; dan 5) produk jadi. Hasil penelitian menunjukkan: 1) Produk souvenir yang berciri khas Universitas Negeri Yogyakarta kurang memberi kesan yang mendalam pada orang yang menerimanya; 2) Perancangan produk souvenir yang berciri khas Universitas Negeri Yogyakarta dilakukan dengan tiga tahap: a) eksplorasi; b) perencanaan; dan c) perwujudan karya, dengan lebih menekankan pada pengembangan jenis produk bernuansa akademik; 3) Keunggulan rancangan produk souvenir yang berciri khas Universitas Negeri Yogyakarta terletak pada: bernuansa akademik, visualisasi UNY pada ornamennya, pemilihan bahan berkualitas, dan keteknikan yang mempertimbangkan nilai estetis.
\end{abstract}

Kata kunci: souvenir, kulit, ciri khas, UNY

\section{SOUVENIR DESIGN BASED ON SKIN TYPICALED OF YOGYAKARTA STATE UNIVERSITY}

\begin{abstract}
The study is a research and development ( $R$ \& D) aims to develop souvenirs typicaled of Yogyakarta State University. This research applies the model of research and development developed Sugiyono (2013: 409) outlining: 1) the potential and problems; 2) data collection; 3) design of the product; 4) evaluation of product design; and 5) the finished product. The results showed: 1) Products souvenir distinctively less Yogyakarta State University gave a deep impression on those who receive it; 2) Design of souvenir products distinctively State University of Yogyakarta done in three stages: a) exploration; b) planning; and c) the embodiment of the work, with more emphasis on the development of products of academic nuance; 3) Excellence souvenir product design distinctively Yogyakarta State University is located in: more nuanced academic, considering the aspects of ergonomics, visualization UNY on the ornaments, the selection of quality materials, and engineering that takes into account the aesthetic value.
\end{abstract}

Keywords: souvenir, skin, typical, UNY 


\section{PENDAHULUAN}

Universitas Negeri Yogyakarta (UNY) merupakan salah satu Lembaga Pencetak Tenaga Kependidikan (LPTK) di Indonesia. Di dalam berkehidupan akademik UNY tentunya telah menjalin hubungan dan kerja sama dengan sesama LPTK maupun lembaga kependidikan maupun non kependidikan yang lainnya baik dalam dari dalam negeri maupun luar negeri. Pelaksanaan kerja sama tentunya tidak menutup kemungkinan untuk saling berkunjung dalam bentuk studi banding, melaksanakan workshop, seminar, pengabdian pada masyarakat, maupun kegiatan pengembangan sumber daya manusia.

Di dalam melakukan kegiatan lawatan, maupun menerima lawatan tidak menutup kemungkinan setiap lembaga meninggalkan cindera mata. souvenir yang tentungan sebagai penghargaan, pengingat, maupun kenang-kenangan antar lembaga satu dengan lainnya.

UNY adalah lembaga pendidikan yang berada di kota pendidikan sekaligus kota budaya dan pariwisata, yang notabene sangat dipertimbangkan dalam urusan mencetak sarjana kependidikan maupun ilmu murni yang tentunya telah memiliki garansi dengan alumni yang terserap di berbagai lini. Selain itu UNY juga sebagai lembaga yang selalu mengikuti perkembangan jaman namun tetap mengangkat budaya lokal, tentunya memiliki daya tawar yang tersendiri. Keberadaan UNY di Yogyakarka, salah satu destinasi wisatawan domestik maupun manca negara, di mana banyak produk budaya berupa artefak seni dan kerajinan yang tersaji dari bahan kayu, keramik, kulit, logam, dan tekstil, menjadikan UNY berada dalam lingkungan budaya adiluhung.

Sebagai lembaga pendidikan yang berkarakter, tidak menutup kemungkinan juga memiliki karakter pada hal yang paling sederhana sampai yang paling penting, misalnya gedung perkuliahan, warna cat gedung perkuliahan, sampai pada hal yang kecil seperti souvenir. Terpikirkan atau belum, sebuah lembaga yang besar sepertinya perlu memiliki persediaan souvenir yang memiliki karakter tentang kelembagaannya tersebut. Souvenir dapat terbuat dari bahan kayu, keramik, kulit, logam, tekstil, atau lainnya. Di antara bahan tersebut, souvenir 
berbahan kulit memiliki kelebihan seperti: awet/tahan lama, fleksibel/luwes, aman, dan memiliki nilai keunikan tersendiri.

Berdasarkan analisis situasi tersebut, maka perlu sekiranya dilakukan pengembangan jenis souvenir yang memiliki karakter dan ciri khas Universitas Negeri Yogyakarta dengan menggunakan bahan kulit. Permasalahan yang akan dipecahkan dalam penelitian ini adalah:

1. Bagaimana produk souvenir yang berciri khas Universitas Negeri Yogyakarta saat ini?

2. Bagaimana perancangan produk souvenir berbahan kulit yang berciri khas Universitas Negeri Yogyakarta?

3. Bagaimana keunggulan rancangan produk souvenir berbahan kulit yang berciri khas Universitas Negeri Yogyakarta?

\section{TINJAUAN PUSTAKA}

\section{Pengertian dan Fungsi Souvenir}

Souvenir merupakan barang-barang kerajinan tangan (handy crafts) yang merupakan hasil kreativitas para perajin yang mampu merubah benda-benda yang tidak berharga menjadi produk-produk kerajinan tangan yang menarik, terutama diminati banyak orang, terutama wisatawan. Dalam kamus The Collins Cobuild Dictionary (2009), dijelaskan bahwa: "Souvenir is usually small and relatively inexpensive article given kept or purchased as a reminder of a place visited, an occasion, etc" (souvenir merupakan benda yang relatif kecil dan harganya tidak mahal, untuk dihadiahkan, disimpan, atau dibeli sebagai kenang-kenangan kepada suatu tempat yang dikunjungi, suatu kejadian tertentu, dan sebagainya). Sementara itu dalam kamus Webster English Dictionary (2004), dijelaskan souvenir diartikan sebagai "an object a traveler bring home for the memories associated with it" (souvenir adalah benda yang dibawa oleh wisatawan sebagai kenang-kenangan bagi perjalannya itu).

Di dalam bahasa Indonesia souvenir sering disebut sebagai cindera mata, oleh-oleh, kenang-kenangan, atau buah tangan. Cindera mata merupakan sesuatu yang dibawa oleh seorang wisatawan ke rumahnya untuk kenangan yang terkait 
dengan benda itu. Cendera mata bisa berupa pakaian seperti kaos atau topi, dan peralatan rumah tangga seperti cangkir atau mangkok, asbak, sendok, maupun buku tulis. Benda-benda tersebut bisa ditulisi untuk menandai asalnya (https://id.wikipedia.org/wiki/Cendera_mata).

Selain sebagai kenang-kenangan, souvenir atau cindera mata juga memiliki beberapa fungsi, di antaranya sebagai berikut. Pertama, sebagai branding perusahaan atau branding produk/jasa perusahaan tertentu, sebagai contoh jam meja yang disablon dengan logo perusahaan dengan harapan ketika diletakkan di meja client maka akan bisa mengingatkan perusahaan pemberi souvenir itu. Selain logo dapat pula motto/tulisan yang bisa mengingatkan client akan perusahaan. Kedua, sebagai ucapan terima kasih atas kehadiran dalam event tertentu atau sebagai cendera mata saat client memasuki acara/undangan perusahaan. Ketiga, sebagai senjata pemasaran dari satu client ke calon client baru lainnya. Sebagai contoh pencantuman logo pada kertas note biasanya digunakan oleh client dalam menulis catatan kecil dan biasanya itu berhubungan dengan pihak ke tiga dari client itu. Hal ini dapat mengingatkan client akan produk/jasa sebuah perusahaan. Keempat, sebagai magnet untuk kumpulan orang agar mampir ke stand pameran/boot yang sedang dibuka disebuah pusat keramaian baik itu mall, seminar, pameran dan sebagainya. Kelima, sebagai pembeda dengan perusahaan lainnya. Di zaman yang persaingan usaha saat ini maka perusahaan yang cenderung berbeda baik dalam hal promosi/pemberian souvenir akan bisa mengisi top of mind brand dalam benak konsumen (http://suppliersouvenir.com/souvenir/5-fungsi-souvenir-perusahaan).

Souvenir dapat dibuat dengan menggunakan bahan yang berbagai macam. Beberapa bahan tersebut adalah, yaitu: serat kayu, rotan, bambu, tempurung kelapa, kulit kerang, kulit siput, kulit hewan, kain, kaos, logam, keramik, kayu, dan masih banyak lagi. Barang-barang souvenir juga bermacam-macam bentuknya, seperti: gantungan kunci, hiasan dinding, asbak rokok, pot bunga, kap lampu, tapal meja, dan masih banyak lagi.

Berdasarkan beberapa penjelasan di atas, dapat ditegaskan bahwa souvenir merupakan benda kenang-kenangan yang berkaitan dengan kegiatan kunjungan, 
perjalanan seseorang, dan suatu peristiwa/kejadian tertentu. Adapun berfungsi souvenir sebagai ucapan pembeda, teknik pemasaran, terima kasih, pengingat, atau perekat hubungan.

\section{Kerajinan Kulit}

Sebelum kita berbicara mengenai kerajinan kulit, baiknya mari kita berusaha memahami apa yang dimaksud dengan kerajinan. Istilah kerajinan dalam bahasa Inggris sering disebut craft. Secara umum, Ensiklopedi Nasional Indonesia (1989: 1479) menjelaskan bahwa arti kerajinan adalah jenis kesenian yang menghasilkan berbagai barang perabot, hiasan atau barang-barang artistik, terbuat dari kayu, besi, porselin, emas, gading, katun, dan sebagai hasil kerajinan juga disebut seni guna. Sementara, dalam Wikipedia Ensiklopedia Bebas (http://id.wikipedia.org/wiki/Kerajinan) menjelaskan bahwa kerajinan adalah hal yang berkaitan dengan buatan tangan atau kegiatan yang berkaitan dengan barang yang dihasilkan melalui keterampilan tangan (kerajinan tangan). Kerajinan yang dibuat biasanya terbuat dari berbagai bahan. Dari kerajinan ini menghasilkan hiasan atau benda seni maupun barang pakai. Biasanya istilah ini diterapkan untuk cara tradisional dalam membuat barang-barang. Senada dengan penjelasan tersebut, Kusnadi (1986: 11) menjelaskan bahwa kerajinan menurut kata harfiahnya dilahirkan oleh sifat rajin manusia. Dalam hal ini sifat terampil tangan manusia yang bermula pengalaman dan ketekunan dalam bekerja, sehingga dapat meningkatkan cara atau teknik penggarapan suatu benda yang merupakan kualitas kerja seseorang, yang akhirnya tercipta produk yang memiliki kualitas yang tinggi. Kerajinan juga sering disebut dengan istilah handycraft yang berarti kerajinan tangan. Kerajinan termasuk seni rupa terapan (applied art) yang selain mempunyai aspek-aspek keindahan juga menekankan aspek kegunaan atau fungsi praktis. Seni kerajinan tangan manusia yang diciptakan untuk memenuhi kebutuhan peralatan kehidupan sehari-hari dengan tidak melupakan pertimbangan artistik dan keindahan. Dari beberapa penjelasan tersebut, dapat ditarik ketegasan bahwa kerajinan (craft) merupakan seni rupa terapan (applied art) yang dicipta 
melalui keterampilan tangan dengan mempertimbangkan aspek keindahan, kegunaan, dan ergonomi.

Selanjutnya, istilah kulit yang di dalam bahasa Inggris leather merupakan bagian terluar dari hewan yang berfungsi sebagai pelindung /pembungkus daging maupun tulang hewan yang sudah dikelupas dari tubuh hewan. Kulit ini dapat berasal dari hewan/binatang mamalia, melata, maupun reptil. Beberapa hewan mamalia yang dapat diambil kulitnya di antaranya: kerbau, sapi, jerapah, gajah, kuda, kambing, domba, kelinci, dan masih banyak lagi. Beberapa hewan yang lain (melata dan reptil,) diantaranya: ular, biawak, komodo, dan lain sebagaiya.

Berdasarkan penjelasan dari penjelasan sebelumnya, maka dapat dijelaskan bahwa kerajinan kulit atau yang sering disebut leather craft (dalam bahasa Inggris) merupakan seni rupa terapan (applied art) berbahan kulit hewan yang dicipta melalui keterampilan tangan dengan mempertimbangkan aspek keindahan, kegunaan, dan ergonomi. Dengan kata lain kerajinan kulit merupakan hasil karya kreatif tangan manusia berbahan kulit hewan yang dibuat dengan kecakapan teknik/keahlian yang tinggi, ketelatenan, kesabaran untuk memenuhi kebutuhan peralatan manusia sehari-hari dengan mempertimbangkan aspek fungsi, aspek artistik, dan keindahan.

Kerajinan kulit merupakan karya yang memiliki nilai fungsi dan nilai keindahan, maka dalam penciptaan kerajinan sangat dipertimbangkan: 1) aspek security yaitu jaminan tentang keamanan orang menggunakan produk kerajinan kulit tersebut; 2) comfortable, yaitu enak digunakan sehingga produk kerajinan kulit memiliki nilai praktis yang tinggi; 3) flexibility, yaitu keluwesan penggunaan, dengan maksud produk kerajinan kulit merupakan barang terap yaitu barang yang wujudnya sesuai dengan kegunaan atau terapannya, sehingga dipersyaratkan memberi kemudahan dan keluwesan penggunaan agar pemakai tidak mengalami kesulitan dalam penggunaannya; 4) produk kerajinan kulit betapapun enaknya dipakai jika tidak enak dipandang maka pemakai produk tersebut tidak merasa puas, dengan maksud produk kerajinan kulit seyogyanya dapat menambah rasa senang, nyaman dan puas bagi pemakainya. 
Jika ditinjau dari segi fungsi dan tujuan, kerajinan kulit memiliki tiga fungsi dan tujuan dalam penciptaannya, yaitu: 1) kerajinan kulit sebagai benda pakai, yaitu produk kerajinan kulit diciptakan sangat mengutamakan aspek fungsi, selanjutnya aspek keindahan muncul sebagai pendukung dan daya tarik; 2) kerajinan kulit sebagai benda hias, dengan maksud seni kerajinan dibuat dengan tujuan utama sebagai benda pajangan atau hiasan, maka kerajinan kulit jenis ini lebih menonjolkan aspek keindahan daripada aspek kegunaan atau segi fungsinya; 3) kerajinan kulit sebagai benda mainan, dalam hal ini kerajinan kulit dibuat untuk digunakan sebagai alat permainan, maka aspek kegunaan dan aspek keindahan menjadi pertimbangan yang tidak utama.

\section{Visi, Misi dan Lambang Universitas Negeri Yogyakarta}

Di dalam http://www.uny.ac.id/profil/visi-misi-dan-tujuan-tahun-2025 (didownload pada 27 Maret 2016) dijelaskan bahwa visi pada tahun 2025 UNY menjadi universitas kependidikan kelas dunia berlandaskan ketaqwaan, kemandirian dan kecendekiaan.

Adapun misi Universitas adalah mendidik manusia dan masyarakat Indonesia dengan :

1. Menyelenggarakan pendidikan akademik, profesi, dan vokasi dalam bidang kependidikan yang didukung bidang nonkependidikan untuk menghasilkan manusia unggul yang mengutamakan ketaqwaan, kemandirian, dan kecendikian.

2. Menyelenggarakan kegiatan penelitian untuk menemukan, mengembangkan, dan menyebarluaskan ilmu pengetahuan, teknologi, seni dan/atau olahraga, yang menyejahterakan individu dan masyarakat, dan mendukung pembangunan daerah dan nasional, serta berkontribusi pada pemecahan masalah global.

3. Menyelenggarakankegiatan pengabdian dan pemberdayaan masyarakat yang mendorong pengembangan potensi manusia, masyarakat, dan alam untuk mewujudkan kesejahteraan masyarakat.

4. Menyelenggarakan tata kelola universitas yang baik, bersih, dan akuntabel dalam pelaksanaan otonomi perguruan tinggi. 
Visi dan misi tersebut tentunya senada dengan makna simbolis yang tertera pada logo Universitas Negeri Yogyakarta. Mardiyono (2008: 9) menjelaskan secara rinci makna lambang UNY dapat dijelaskan sebagai berikut.

\section{Bentuk Dasar}

Bunga teratai digambarkan dalam padma persegi lima, melambangkan pancasila sebagai filosofi dasar gerak, dan warna kuning kontur untuk menyatakan kejayaan

2. Warna Dasar

Biru merupakan warna netral yang melambangkan kedalaman jiwa, keteguhan jiwa, kewibawaan dan kemantapan langkah, dan warna ini berkesan tenang melambangkan pendidikan tinggi harus dijiwai kedalaman berpikir , kewibawaan tinggi dan mantap dalam setiap langkah dan geraknya.

\section{Tulisan Universitas Negeri Yogyakarta}

Tulisan Universitas Negeri Yogyakarta dibuat melingkar melambangkan globe dunia bersambung dengan tulisan kaligrafi UNY.

\section{Gambar Sayap Berwarna Kuning}

Bentuk ini melambangkan pengembangan program-program universitas, baik nasional regional maupun internasional. Sayap diberi rangka berbentuk harpha (alat musiK tradisional) melambangkan pengembangan kebudayaan.

1. Gambar Tugu

Gambar Tugu adalah deformasi Tugu Yogyakarta sebagai ciri khas kota Yogyakarta, disamping menggambarkan arsitektur (teknologi), tugu juga melambangkan keteguhan sivitas akademika dalam melaksanakan tridarma. Pada gambar tugu terdapat: a) mustaka berbentuk api terbilah tiga dengan warna merah melambangkan tridarma; b) tangga, dada, dan tubuh tugu yang berbentuk pena melambangkan pendidikan; c) kaki tugu berbentuk tangga melambangkan jenjang pendidikan. 


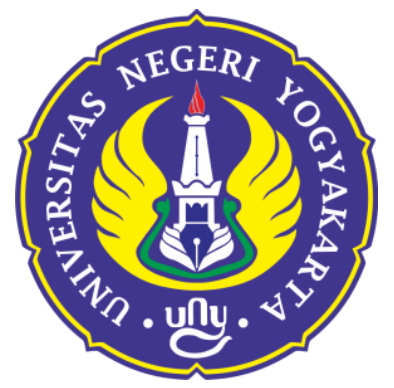

Gambar 1: Lambang UNY

(Sumber: Mardiyono, 2008: 9)

\section{HASIL DAN PEMBAHASAN}

\section{Konsep Pengembangan}

\section{Model Pengembangan}

Penelitian dan pengembangan merupakan penelitian yang menghasilkan rancangan produk souvenir yang berciri khas Universitas Negeri Yogyakarta. Konsep pengembangan dalam penelitian ini mengacu pada model yang dikembangkan oleh Sugiyono (2016: 11). Secara garis besar model pengembangan yang dijadikan sebagai landasan dalam penelitian ini adalah sebagai berikut.

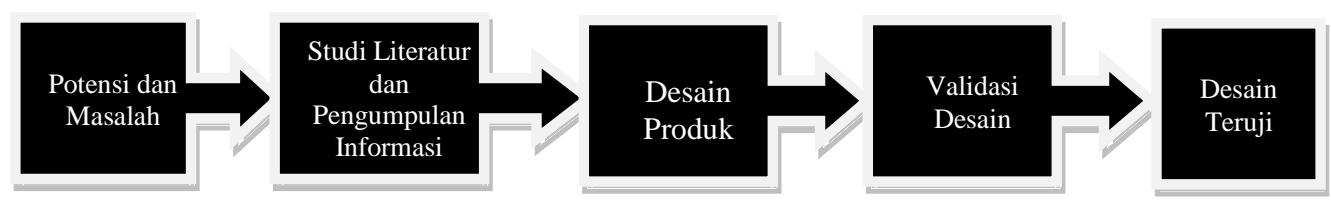

Gambar 2. Model Pengembangan Souvenir berciri Khas UNY

Secara rinci langkah-langkah pengembangan tersebut sebagai berikut.

a. Potensi dan Masalah

Penggalian potendi dengan melakukan analisis potensi bentuk, dekorasi, bahan, alat, teknik, dan sumber daya manusia dalam pembuatan souvenir. Pencarian masalah dilakukan dengan analisis produk souvenir yang berciri khas Universitas Negeri Yogyakarta yang ada saat ini.

b. Studi Literatur dan Pengumpulan Informasi 
Studi literatur dan pengumpulan informasi meliputi aspek: pengertian, fungsi, bentuk, dekorasi, bahan, alat, dan teknik pembuatan souvenir, dan kebutuhan akan souvenir.

c. Desain Produk / Pembuatan rancangan produk souvenir

Desain produk merupakan tahapan pembuatan rancanagan produk souvenir dengan tahapan sebagai berikut.

1) Melakukan eksplorasi dan menuangkan gagasan.

2) Visualisasi ide dan gagasan ke dalam bentuk visual dua dimensi

3) Perwujudan

d. Validasi Desain

Validasi desain meliputi validasi kepada ahli/pakar yang dilanjutkan merevisi rancangan produk berdasarkan saran dan beberapa masukan dari ahli/pakar.

e. Desain Teruji

Desain teruji merupakan rancangan souvenir yang sudah melalui revisi berdasarkan saran dan masukan dari pakat/ahli.

\section{Instrumen dan Teknik Analisis Data}

Dalam penelitian ini instrumen utama dalam penelitian ini adalah peneliti sendiri dan didukung instrumen lain berupa kuesioner, pedoman wawancara, dan pedoman observasi. Data yang diperoleh dari responden berdasarkan wawancara dan observasi diolah dan dianalisis secara deskriptif kualitatif. Data yang diperoleh dari kuesioner dinanalisis deskriptif kuantitatif

\section{Jenis Bahan}

Jenis bahan yang digunakan pada pengembangan souvenis ini adalah bahan kulit tersamak nabati yang berasal dari kulit sapi. Pemilihan kulit sapi ini didasarkan ketebalan yang cukup memungkinkan dilakukan pembuatan dekorasi dengan teknik tatah timbul (carving). Selain itu pemilihan bahan ini didasarkan pada tekstur permukaan kulit sapi yang lebih halus jika dibandingkan denga kulit kerbau, kambing, domba, atau sejenisnya. Dengan membertimbangkan berbagai bahan ini diharapkan akan mendapatkan jenis produk souvenir yang memiliki kualitas tinggi. 


\section{Ornamen dan Teknik Penghias Permukaan}

Di dalam menghias permukaan kulit, dikombinasikan unsur perlambang Universitas Negeri Yogyakarta dan beberapa bentuk yang lain yang memiliki makna yang sinonim dan mendukung visi dan misi Universitas Negeri Yogyakarta. Keteknikan yang diterapkan adalah teknik tatah timbul (carving), sehingga akan dihasilkan dekorasi berupa relief pada permukaan souvenir.

\section{Produk Souvenir yang Berciri Khas Universitas Negeri Yogyakarta Saat ini}

Produk souvenir yang terpajang di beberapa showroom di lingkungan Universitas Negeri Yogyakarta saat ini memiliki kecenderungan biasa dan kurang memberi kesan yang mendalam pada orang yang menerimanya. Hal ini jelas kurang sesuai dengan karakter souvenir, di mana sebuah souvenir tentunya sebuah benda yang dapat memberi kenang-kenangan yang berkaitan dengan kegiatan kunjungan, perjalanan seseorang, dan suatu peristiwa/kejadian tertentu. Selain itu souvenir seyogyanya berfungsi sebagai pembeda, teknik pemasaran, ucapan terima kasih, pengingat, atau perekat hubungan yang telah dibangun kedua lembaga atau instansi. Hal ini dikarenakan bentuk biasa seperti souvenir pada umumnya, misalnya kurang ada variasi, keunikan, nuansa akademik, dan kebaruan dari sisi bentuk, jenis/ragam produk, bahan, teknik pembuatan, dan dekorasi/ornamen. Di antara souvenir yang ada sebagian besar kurang dapat menunjukkan souvenir yang bernuansa akademik. Universitas Negeri Yogyakarta (UNY) merupakan sebuah lembaga yang konsen di bidang akademik dan mencerdaskan kehidupan bangsa. Sangat memungkinkan UNY bekerja sama dengan lembaga dengan bidang konsentrasi yang sejenis. Maka tidak menutup kemungkinan saling memberi kenang-kenangan berupa cindera mata/souvenir yang mewakili karakter lembaga masing-masing. Khususnya UNY sangat memungkinkan adanya souvenir yang berkaitan dengan nuansa edukasi dan pembelajaran. Beberapa hal ini belum terlihat saat ini. Souvenir yang ada sebenarnya telah mewakili branding sebuah lembaga, sebagai contoh adanya 
logo atau motto/tulisan yang bisa mengingatkan orang lain akan keberadaan UNY, namun kurang dapat memberi pembeda dengan universitas lain, dalam hal ini dari sisi bahan dan keteknikan. Padahal, di zaman yang persaingan ketat saat ini maka institusi yang cenderung berbeda baik dalam hal promosi/pemberian souvenir akan bisa mengisi top of mind brand dalam benak penerima souvenir.

\section{Perancangan Produk Souvenir Berbahan Kulit yang Berciri Khas Universitas Negeri Yogyakarta}

Rancangan produk souvenir berbahan kulit berciri khas Universitas Negeri Yogyakarta dijalankan melalui beberapa langkah, di antaranya: a) mencari potensi dan masalah dengan melakukan analisis potensi bentuk, dekorasi, bahan, alat, teknik, dan sumber daya manusia dalam pembuatan souvenir dan melakukan analisis permasalahan terkait produk souvenir yang berciri khas Universitas Negeri Yogyakarta; b) studi literatur (pengertian, fungsi, bentuk, dekorasi, bahan, alat, dan teknik pembuatan souvenir) dan mengumpulkan informasi terkait perkembangan serta kebutuhan akan souvenir; dan c) mengembangkan produk dengan membuat rancangan produk souvenir. Selanjutnya beberapa langkah dapat dijelaskan sebagai berikut.

\section{a. Pencarian Potensi dan Masalah}

Pencarian potensi dalam mengembangkan souvenir yang berciri khas Universitas Negeri Yogyakarta adalah: 1) masih banyaknya bentuk-bentuk souvenir yang dapat dieksplorasi, misalnya sampul buku agenda, tempat flashdis, tempat pensil, bingkai foto, berbagai bentuk gantungan kunci, berbagai dompet pria maupun wanita, tas laptop atau netbook; 2) sangat memungkinkan mengeksplorasi penjabaran komponen pembentuk logo UNY sebagai dekorasi/ornamen; 3) banyaknya bahan untuk pembuatan souvenir termasuk kayu, keramik, kulit, logam, tekstil, bahkan batuan; 4) banyaknya kemungkinan keteknikan yang dapat diterapkan dalam membuat souvenir dengan mengadaptasikan bahan yang digunakan, misalnya ukir kayu, teknik pijit keramik, tatah timbul (carving) kulit, patri logam, atau makrame tekstil. 
Setelah dilakukan pencarian permasalahan pada produk souvenir yang berciri khas Universitas Negeri Yogyakarta saat ini, maka diketahui beberapa masalah yaitu: 1) kurangnya diversifikasi produk souvenir; 2) kurang mengeplorasi logo UNY sebagai ornamen/dekorasi souvenir; 3) kurang bervasiasinya bahan-bahan yang dapat digunakan untuk membuat souvenir; 4) masih terbatasnya keteknikan pada pembuatan souvenir, sehingga kurang memberi kesan yang mendalam dan keunikan tersentiri. Selama ini lebih dominan menggunakan teknik sablon pada beberapa souvenir, sehingga terkesan monoton dan kurang menarik.

\section{b. Studi Literatur dan Mengumpulkan Informasi}

Studi literatur yang dilakukan adalah menggali literasi tentang pengertian, fungsi, macam bentuk, nilai ergonomis, dan nilai keindahan. Maka kajian literasi ini mencakup: 1) aspek security yaitu jaminan tentang keamanan orang menggunakan produk souvenir tersebut;2) comfortable, yaitu enak digunakan sehingga produk souvenir memiliki nilai praktis yang tinggi; 3) flexibility, yaitu keluwesan penggunaan, dengan maksud produk souvenir merupakan barang terap yaitu barang yang wujudnya sesuai dengan kegunaan atau terapannya, sehingga dipersyaratkan memberi kemudahan dan keluwesan penggunaan agar pemakai tidak mengalami kesulitan dalam penggunaannya; 4) produk souvenir betapapun enaknya dipakai jika tidak enak dipandang maka pemakai produk tersebut tidak merasa puas, dengan maksud produk souvenir seyogyanya dapat menambah rasa senang, nyaman dan puas bagi pemakainya sehingga akan dikenang oleh yang menerima souvenir tersebut.

Pengumpulan informasi ini diawali dengan melakukan analisis situasi di lapangan dengan melakukan pengamatan (observasi) di berbagai showroom seperti laboratorium kewirausahaan Universitas Negeri Yogyakarta dan Koperasi Mahasiswa (Kopma) Universitas Negeri Yogyakarta. Selain dilakukan wawancara dengan pegawai showroom terkait dengan masalah dan kebutuhan desain souvenir yang berciri khas UNY. Penggalian informasi terkait souvenir yang ada apakah telah 
mempertimbangkan aspek estetis, aspek fungsi, dan aspek ergonomi. Selain itu juga digali informasi terkait dengan kontur, bentuk, warna, tekstur, , bahan, dan teknik yang sangat terkait dengan kenyamanan, keamanan, kesehatan, dan aspek ekonomi.

\section{c. Mengembangkan/Membuat Rancangan Produk}

Pengembangan produk dalam hal ini adalah mengawali membuat rancangan produk souvenir dengan menggunakan tahapan penciptaan kriya dengan mengadopsi Gustami (2007: 329), yaitu terdapat tiga tahapan dalam mencipta karya kriya: 1) tahap eksplorasi; 2) tahap perencanaan/desain; dan 3) tahap perwujudan karya. Selanjutnya, secara rinci langkah-langkah pengembangan tersebut sebagai berikut.

1) Tahap eksplorasi dan menuangkan gagasan

Tahapan eksplorasi ini merupakan tahapan dimana dilakukan observasi, penggalian sumber dan referensi terkait souvenir dan beberapa hal tentang Universitas Negeri Yogyakarta. Selain itu juga melakukan pengamatan, wawancara, studi pustaka, dan pendokumentasian. Penggalian acuan visual juga dilakukan pada tahap ini sehingga diketahui secara komprehensif bentuk, ukuran, warna, dan tekstur.

Akhir dari kegiatan eksplorasi adalah menuangkan ide dan gagasan dengan mempertimbangkan beberaapa aspek, yaitu: estetika, fungsi, material, teknik, proses, ergonomi, keamanan, kenyamanan, filosofi, sosial, dan ekonomi. Penuangan ide dan gagasan berupa beberapa sket produk souvenir. Berdasarkan analisi hasil observasi, wawancara, pendokumentasian, penggalian sumber dan referensi terkait souvenir dan beberapa hal tentang Universitas Negeri Yogyakarta, maka dituangkan sket berupa sampul buku agenda, dompet, tempat flashdis, dan gantungan kunci.

2) Perencanaan

Perencanaan merupakan visualisasi ide dan gagasan ke dalam bentuk visual dua dimensi. Adapun dalam perencanaan ini meliputi: 1) 
pembuatan gambar tampak depan, samping, dan atas; 2) pembuatan gambar detail ornamen; dan 3) pembuatan gambar perspektif berwarna.

Pembuatan gambar depan dalam hal ini untuk mengetahui rancangan produk souvenir dari sisi depan terkait bentuk, ukuran, dan lokasi ornamen/deorasi. Gambar tampak depan dibuat berskala 1:1 untuk rancangan produk sampul buku agenda, bingkai foto, dan dompet, skala 2:1 untuk gantungan kunci dan tempat flashdis.

Gambar detail ornamen dalam hal ini merupakan gambar yang mendeskripsikan secara detail ornamen atau dekorasi dari masing-masing jenis souvenir. Ormamen pada sampul buku agenda berupa logo UNY berdiameter $6 \mathrm{~cm}$ yang dipangku dengan stilisasi teratai, yang bungan teratai merupakan bagian dari pembentuk logo UNY. Ornamen pada produk bingkai foto berupa kaligrafi tulisan "Universitas Negeri Yogyakarta" dan "UNY" yang ditata oval dengan susunan "Universitas" di disisi kiri, "Negeri" di sisi atas, "Yogyakarta" di sisi kanan, dan "UNY" di sisi bawah. Ornamen pada dompet standart pria berupa stilisai bunga teratai yang dipadu dengan lakigrafi UNY. Ornamen/dekorasi pada tempat flashdis berupa kaligrafi UNY yang terletak pada bagian tutup. Selanjutnya, ornamen/dekorasi produk gantungan kunci berupa logo UNY dengan diameter $6 \mathrm{~cm}$.

Gambar perspektif berwarna merupakan gambar mendeskripsikan produk souvenir dari sisi perspektif dan berwarna sesuai dengan perencanaan warna yang diinginkan. Perspektif ini seolah kesan mata melihat secara langsung atau seperti foto karya yang sebenarnya.

3) Perwujudan

Perwujudan merupakan tahapan membuat rancangan yang berpedoman pada perencanaan yang selanjutnya diwujudkan menjadi karya nyata dengan tahapan: 1) pembuatan pola; 2) pemotongan bahan; 3) pembuatan ornamen (dengan teknik tatah timbul / carving); 4) penyesetan; 5) perakitan dan penjahitan; dan 6) penyelesaian akhir. 
Pembuatan pola ini merupakan awal perwujudan dari masingmasing rancangan produk souvenir. Dalam pembuatan pola ini digunakan kertas malaga (duplek) yang memiliki karakter kertas ulet dan kuat. Pemilihan kertas ini bertujuan agar pola yang dibuat kuat, tidak mudah berubah bentuk dan ukuran.

Pemotongan bahan kulit dilakukan dengan mempertimbangkan arah kemuluran dan ketegangan kulit. Hal ini dimaksudkan agar produk souvenir tercapai stadar ergonominya. Selain itu, dalam pemotongan pola juga mempertimbangkan kaidah saling mengunci (interlocking) dengan pertimbangan pemanfaatan bahan yang maksimal dan menghindari terbuangnya bahan kulit.

Pembuatan ornamen dilakukan setelah semua komponen pembentuk souvenir sudah terpotong dan belum dilakukan tahapan perakitan antar komponen. Hal ini dimaksudkan agar mempermudah dalam proses pendekorasian dengan teknik tatah timbul/carving.

Penyesetan yang dilakukan pada pembuatan souvenir ini adalah sesetan miring, yaitu untuk mengurangi ketebalan kulit bagian tepi dengan hasil sesetan pada penampang kulit yang diseset jika dilihat dari samping miring/bersudut. Penyesetan miring ini juga dilakukan pada bagian tepi komponen souvenir yang akan dilakukan jahit tumpang.

Penjahitan dalam pembuatan souvenir ini dilakukan secara manual. Penjahitan manual merupakan penjahitan yang dilakukan dengan tangan. Adapun alat yang digunakan dalam penjahitan secara manual adalah: jarum jahit manual (jarum tangan), rader (penanda), uncek, plong ganda (pelobang jahitan), palu, penjepit.

Penyelesaian akhir pada pembuatan rancangan souvenir ini dengan merapikan sisa dengan menggunakan pemanas solder, menghilangkan sisa lem dengan karet mentah, dan pengkilapan permukaan produk dengan pemberian cairan penutup pori-pori kulit dan pengecatan permukaan kulit dengan menggunakan warna coklat. 


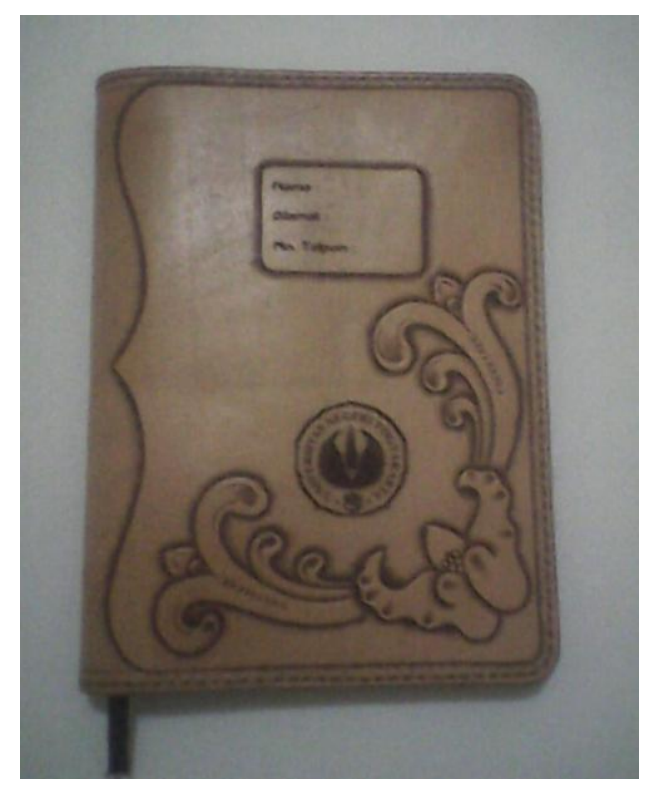

Gambar 3: Rancangan Sampul Buku Agenda

\section{Keunggulan Rancangan Produk Souvenir Berbahan Kulit yang Berciri Khas Universitas Negeri Yogyakarta}

Keunggulan rancangan produk merupakan sesuatu yang utama dalam penelitian dan pengembangan. Tentunya dalam pengembangan rancangan produk memiliki keunggulan, di mana keungulan tersebut merupakan hasil pengembangan yang bersandar pada refleksi permasalahan yang ada yang didapatkan dari analisis souvenir yang ada saat ini. Rancangan produk souvenir berbahan kulit ini memiliki keunggulan/kelebihan dari aspek jenis produk, bentuk, dekorasi/ornamen, bahan, dan keteknikan.

Jenis produk rancangan souvenir yang dikembangkan ini lebih bernuansa akademik. Hal ini terlihat pada jenis rancangan souvenir berupa sampul buku agenda, tempat flashdis, meski ada jenis produk yang lain seperti dompet pria standart, bingkai foto, dan gantunga kunci. Hal ini seiring dengan karakter lembaga Universitas Negeri Yogyakarta yang bergerak di bidang pendidikan dan pengajaran.

Aspek bentuk dalam rancangan produk souvenir ini lebih menonjol pada rancangan bentuk yang tidak bersudut. Maksud dari penjelasan ini adalah pertemuan pada setiap sisinya selalu membentuk garis 
lengkung/melengkung. Bentuk ini memberi kesan luwes tidak kaku pada setiap rancangan produk. Secara ergonomi, bentuk yang tidak bersudut memberi kenyamanan dalam pemakaian dan menghidari kerusakan pada setiap ujungnya. Kelebihan ini sangat terlihat pada rancangan produk dompet pria standart, yaitu produk ini akan mudah dan nyaman dimasukkan dalam saku karena tidak takut menyangkut pada setiap sudutnya (karena setiap sudutnya dibuat lengkung).

Pada aspek dekorasi/ornamen, rancangan produk souvenir ini lebih mengutamakan visualisasi logo Universitas Negeri Yogyakarta pada setiap permukaan souvenir. Hal ini dimaksudkan agar produk souvenir yang berciri khas Universitas Negeri Yogyakarta saat ini lebih memberi kesan yang mendalam pada orang yang menerimanya. Hal ini sesuai dengan karakter souvenir, di mana produk souvenir seyogyanya dapat memberi kenangkenangan yang berkaitan dengan kegiatan kunjungan, perjalanan seseorang/lembaga, dan suatu peristiwa/kejadian tertentu misalnya seminar yang diselenggarakan oleh dan atau di Universitas Negeri Yogyakarta. Selain itu souvenir dengan visualisasi logo UNY ini berfungsi sebagai pembeda, teknik pemasaran, pengingat, atau perekat hubungan yang telah dibangun antara UNY dengan instansi/lembaga lain.

Keunggulan lainnya terlihat pada aspek bahan dan keteknikan dekorasi. Pemilihan bahan berupa kulit sapi yang disamak nabati memiliki sifat awet/tahan lama yang merupakan karakter dari roduk berbahan kulit. Kulit samak nabati lebih memungkinkan dapat dihias permukaanya/didekorasi dengan teknik tatah timbul/carving dibandingkan dengan kulit tersamak lainnya. Karakter bahan ini sangat memungkinkan diciptanya dekorasi/ornamen yang tidak hanya sekedar mencipta ornamen berupa bentuk, tetapi juga mencipta tekstur yang unik dan memiliki nilai estetis yang tinggi. 


\section{KESIMPULAN}

Produk souvenir yang berciri khas Universitas Negeri Yogyakarta saat ini memiliki kecenderungan biasa dan kurang memberi kesan yang mendalam pada orang yang menerimanya. Hal ini terlihat pada aspek jenis produk , bentuk, dekorasi/ornamen, bahan, dan keteknikan.

perancangan produk souvenir yang berciri khas Universitas Negeri Yogyakarta lakukan dengan tiga tahapan: a) tahap eksplorasi; b) tahap perencanaan/desain; dan c) tahap perwujudan karya, dengan lebih menekankan pada pengembangan jenis produk bernuansa akademik, bentuk mempertimbangkan aspek ergonomi, dekorasi/ornamen mencerminkan UNY, bahan dan keteknikan yang berkualitas dan memiliki nilai unik.

Keunggulan rancangan produk souvenir yang berciri khas Universitas Negeri Yogyakarta terletak pada: lebih bernuansa akademik, mempertimbangkan aspek ergonomi, visualisasi UNY pada ornamennya, pemilihan bahan berkualitas dan keteknikan yang mempertimbangkan nilai estetis.

\section{DAFTAR PUSTAKA}

Anonim. "Creative Industries Economic Estimates" dalam Department for Culture, Media and Sport. Statistical Release. edisi Januari 2015.

Anonim. 2009. The Collins Cobuild Dictionary

Anonim. 2004. Webster English Dictionary

Gustami, SP. 2007. Butir-Butir Mutiara Estetika Timur Ide Dasar Penciptaan Seni Kriya Indonesia. Yogyakarta: Prasista

https://id.wikipedia.org/wiki/Cendera_mata. Diunduh 27 Maret 2016

Kusnadi, 1986. Persan Seni Kerajinan Tradisonal dan Baru. Majalah seni XVII. Yogyakarta: STSR "ASRI"

Mardiyono, Sugeng. 2008. Kajian Filosofi Universitas Negeri Yogyakarta. Yogyakarta: Universitas Negeri Yogyakarta 
Sugiyono. 2013. Metode Penelitian Pendidikan Pendekatan Kuantitatif, Kualitatif, dan $R \& D$. Bandung: Alfabeta 2016. "Metode Penelitian dan Pengembangan". Makalah disampaikan di hadapan dosen FBS UNY, tanggal 26 Juli 2016, di LMT FBS UNY.

Tim Bengkel Kulit. 2000. Bahan Ajar SMK Kria Kulit. Yogyakarta: Pusat Pengembangan Penataran Guru Kesenian, Direktorat Jenderal Pendidikaan Dasar dan Menengah, Departemen Pendidikan Nasional.

Wikipedia Ensiklopedia Bebas dalam http://id.wikipedia.org/wiki/Kerajinan (diunduh tanggal 4 Oktober 2015). 